\title{
Stakeholder marketing: theoretical foundations and required capabilities
}

\author{
Bas Hillebrand • Paul H. Driessen • Oliver Koll
}

Received: 14 May 2014 / Accepted: 8 January 2015 / Published online: 31 January 2015

(C) The Author(s) 2015. This article is published with open access at Springerlink.com

\begin{abstract}
This conceptual paper argues that the marketing discipline should move away from its rather restrictive focus on customers toward a view of marketing that acknowledges the interrelatedness of stakeholders. Building on multiplicity theory, this paper presents stakeholder marketing as a revised perspective on marketing that views stakeholder networks as continuous instead of discrete multiplicities. This revised perspective offers a better understanding of stakeholder networks where (1) value exchange has become complex rather than dyadic, (2) tension between stakeholder interests has become explicit rather than implicit, and (3) control over marketing activities has become dispersed rather than centralized. The paper conceptualizes capabilities required by firms for dealing with each of these three transitions: systems thinking, paradoxical thinking, and democratic thinking. The paper discusses implications for firm performance, marketing theory, empirical research, and marketing practice and argues that embracing stakeholder marketing helps to reclaim territory for marketing in academia and business.
\end{abstract}

Keywords Stakeholder marketing · Marketing theory · Networks $\cdot$ Capabilities $\cdot$ Multiplicity $\cdot$ Conceptual paper

B. Hillebrand $(\bowtie) \cdot$ P. H. Driessen

Institute for Management Research, Radboud University Nijmegen, P.O. Box 9108, 6500HK Nijmegen, The Netherlands

e-mail: b.hillebrand@fm.ru.nl

P. H. Driessen

e-mail: p.driessen@fm.ru.nl

O. Koll

School of Management, University of Innsbruck, Universitätsstraße

15, 6020 Innsbruck, Austria

e-mail: oliver.koll@uibk.ac.at

\section{Introduction}

The brand image of football team Washington Redskins is affected by the team owners taking branding decisions, advocacy groups claiming the brand name to be racist, sponsors linking their brand to the team, fans holding strong feelings towards the brand, regulators cancelling trademarks, the Washington DC city council seeking positive associations with their city, and other politicians voicing their opinion about the brand name.

The distribution of Netflix's online streaming services relies on internet service providers deploying sufficient bandwidth, device manufacturers offering technology for playback, customers adopting such technology, production companies making content available, and lawmakers supporting net neutrality.

The marketing success of Pfizer's new medicine to treat rheumatoid arthritis, Xeljanz, depends on physicians prescribing the medicine, nurses educating patients, insurance companies providing coverage, patient advocacy groups endorsing the treatment, and regulatory bodies approving the product.

Examples such as these and the growing literature on stakeholder marketing have sensitized marketers to look beyond the customer as the focal stakeholder. Marketing scholars have argued that marketing should pay attention not just to customers, but also to other stakeholders such as governments, suppliers, trade unions, and NGOs. As early as 1972, Philip 
Kotler noted that "marketing is a relevant subject for all organizations in their relations with all their publics, not only customers" (Kotler 1972, p. 47, emphasis added). Despite this and other calls for a broader perspective in marketing (see, e.g., Bagozzi 1975; Day and Wensley 1983; Gummesson 2008; Hult et al. 2011; Lusch and Webster 2011), for a long time most marketing research has remained focused on customer relationships.

Recently, the introduction of the notion of stakeholder marketing (Bhattacharya and Korschun 2008) has raised renewed attention for the existence of an extended number of stakeholders. Stakeholder marketing is defined as "activities within a system of social institutions and processes for facilitating and maintaining value through exchange relationships with multiple stakeholders" (Hult et al. 2011, p. 57). It focuses on co-creation in network relationships rather than just dyadic relationships and acknowledges the potential of indirect creation of value (Frow and Payne 2011; Hult et al. 2011). Stakeholder marketing recognizes that customer relationships may be influenced by relationships with other stakeholders and that a diverse network of stakeholders creates value (Gummesson 2008). Special issues on stakeholder marketing (e.g., European Journal of Marketing in 2005, Journal of Public Policy and Marketing in 2010) as well as calls for inclusion of stakeholders in formal definitions of marketing (Gundlach and Wilkie 2009; Smith et al. 2010) underscore the increasing acceptance of a stakeholder perspective in marketing.

Despite the growing attention to stakeholder marketing, mainstream marketing literature to date has not gone much further than observing that firms have multiple stakeholders. Implicitly or explicitly, stakeholders have been dealt with by simply "adding" other stakeholders or stakeholder groups to the one stakeholder group marketing is usually concerned with: customers (Hill and Martin 2014). In doing so, marketing literature has employed a "hub-and-spokes" perspective, in which a firm (the hub) maintains dyadic relationships with separate stakeholder groups (the spokes) (Ritter and Gemünden 2003; Neville and Menguc 2006). However, stakeholders themselves are interrelated in networks (Dhanaraj and Parkhe 2006). Having to deal with multiple interrelated stakeholders (instead of multiple unrelated stakeholders) confronts a firm with different types of problems rather than just more of the same types of problems. As the current hub-and-spokes perspective does not fully reflect the problems that marketing managers experience in a complex network of interrelated stakeholders (Gummesson 2008), there is a need for a new perspective on the marketing discipline that recognizes that stakeholders are interrelated.

The first contribution of this conceptual paper to existing marketing literature is to provide a perspective on the marketing discipline that takes the interrelatedness of stakeholders into account. We present a "revised theoretical perspective" (MacInnis 2011) on the marketing discipline and contrast it with the prevailing perspective on marketing. In earlier times the marketing discipline, adopting a systems perspective, acknowledged the fact that a firm is embedded in a larger network of actors (e.g., Alderson 1957; Fisk 1967). Since then, the discipline has increasingly ignored the system and has focused on transactions with only one stakeholder group, customers. Later, this transactional perspective was replaced by a relational perspective (Grönroos 1990; Morgan and Hunt 1994; Berry 1995). The relational perspective has since then remained the dominant perspective in marketing and has been extended to include co-creation, i.e., joint value creation with customers (Vargo and Lusch 2004). Although literature from the relational perspective has acknowledged that relationships with multiple stakeholders matter and that insights from the relationship marketing literature may be helpful in understanding relationships with non-customer stakeholders as well (Grönroos 1990; Berry 1995; Payne and Frow 2005), most of the marketing discipline has not fully embraced this notion and has kept the customer in the focus of attention. Similarly, most studies taking a relational perspective on supply chains have focused on the buyer-supplier dyad, although some authors have started to investigate the networks in which relationships exist (e.g., Wathne and Heide 2004). We argue that the marketing discipline should move further away from its rather restrictive focus on customers toward a view of marketing that embraces other stakeholders and the interrelations between them. Relying on multiplicity theory, we describe a revised theoretical perspective on marketing and explain why this revised perspective provides a better understanding of the nature of value creation in current realities of complex stakeholder networks.

The second contribution of this paper is a proposed set of specific capabilities that firms require in order to meet new challenges arising from complex stakeholder networks. The literature to date does not identify specific capabilities that firms need for dealing with the interrelatedness of stakeholders, thus representing a "marketing capability gap" (Day 2011). We show that stakeholder marketing requires the following capabilities: systems thinking, paradoxical thinking, and democratic thinking. In doing so, we respond to Day's (2011) call for the identification of "open marketing" capabilities in network organizations. We propose a set of specific actions to build and improve these capabilities in firms. Embracing a stakeholder marketing perspective and developing the associated capabilities may be a promising avenue to overcome the declining influence of marketing in firms that several marketing academics have noted (e.g., Verhoef and Leeflang 2009; Webster and Lusch 2013).

The new perspective and associated capabilities may not be equally important for every industry, firm, marketing executive or marketing activity. In some cases, marketing managers may do well by focusing on customers only, which can be very challenging in itself. In such situations, adopting stakeholder marketing may unnecessarily complicate the work of marketers. Yet, at the same time we notice that in an increasing number of industries marketers have little choice but to embrace stakeholder marketing. For example, the pervasiveness of internet and the transparency it brings (Van Bruggen et al. 
2010), as well as the growing importance of service constellations (Edvardsson et al. 2011; Tax et al. 2013), have increased the interrelatedness of stakeholders in many industries. Such exogenous developments have transformed stakeholder networks to be characterized by complex (rather than dyadic) value exchange, explicit (rather than implicit) tension between stakeholder interests, and dispersed (rather than centralized) control over marketing decisions. The more a stakeholder network has undergone these transitions, the bigger the need for marketing managers to adopt stakeholder marketing.

In the following, we first provide a short overview of stakeholder theory. Next, we explain the concept of multiplicity and discuss how multiplicity theory provides a revised perspective on marketing. We then discuss how this revised perspective leads to a better understanding in many contexts: we describe three transitions in marketing practice that make the traditional perspective on stakeholder networks increasingly inappropriate and consequently call for new capabilities for dealing with these transitions. We describe the revised perspective through declarative premises that conceptualize the main building blocks. We then discuss the consequences that this revised marketing perspective has for firm performance, marketing theory, future marketing research, and managerial practice. Finally, we argue that stakeholder marketing helps marketing to regain territory in academia and business.

\section{Stakeholder theory}

While several authors have stressed the importance of an organization's constituencies before, Freeman (1984) is credited with having formally introduced the concept of stakeholders to the academic debate by developing stakeholder theory. Stakeholders are defined as "any group or individual who can affect or is affected by the achievement of the organization's objectives" (Freeman 1984, p. 46). Freeman's (1984) major contribution was to advise organizations to balance differing stakeholder interests, rather than focus on maximizing the benefits of one stakeholder (Clarkson 1995). Stakeholder theory describes and advocates "simultaneous attention to the legitimate interests of all appropriate stakeholders" (Donaldson and Preston 1995, p. 67). Although stakeholder theory is sometimes regarded as conflicting with theories of the firm rooted in economics, this is not necessarily the case. In fact, stakeholder theory may be regarded as an extension of agency theory because managers are viewed as agents not just for shareholders, but for all stakeholders (Hill and Jones 1992; Hult 2011).

While many believe that stakeholder theory is in essence normative (as a theory dealing with the ethics and morality of business), it is also instrumental (as a theory dealing with the effectiveness of business) (Preston and Donaldson 1999; Jones and Wicks 1999; Parmar et al. 2010). Stakeholder theory not only provides a framework for how organizations ought to do business but also suggests that paying attention to multiple stakeholders secures tangible and intangible resources (including knowledge and reputation) that may ultimately create organizational wealth or value for shareholders. Freeman (1999) even argues that the normative and instrumental aspects of stakeholder theory should not be separated because stakeholder theory is a way to understand how ethical principles lead to economic advantage in the long term (see also Jones 1995). While limited in number, some studies have empirically shown that organizations paying attention to multiple stakeholders perform better (e.g., Homburg et al. 2013; Koll et al. 2005; Luo and Bhattacharya 2009; Sisodia et al. 2007).

Scholarly work on stakeholder theory, although holistic in its aim and origin, remains mostly focused on dyadic relationships and does not capture the complex interactions within the stakeholder network to their full extent (Neville and Menguc 2006). To provide a better notion of this complexity, we now move to multiplicity theory.

\section{Multiplicity theory and stakeholder marketing}

The concept of multiplicity originates from Bergsonian philosophy (Bergson 1910). A multiplicity is an "assemblage," an entity that is constituted by the conjunctive synthesis of a number of simple elements or singularities (Styhre 2002; Tampio 2010). For example, a sand dune can be considered an assemblage consisting of simple elements: grains of sand. Bergsonian philosophy offers us two perspectives on viewing multiplicities: they may be regarded as discrete multiplicities or as continuous multiplicities (Deleuze 1988). Considering multiplicities as discrete implies that multiplicities are homogeneous and countable. A discrete multiplicity does not change in nature when divided; it changes only in degree because all the elements are considered the same in kind. Discrete multiplicities are objective, actual, and leave no room for multiple parallel interpretations at the same time. In the discrete multiplicity perspective, a valid way to understand the entire multiplicity is to sequentially focus on the elements within the multiplicity as if they are independent of each other. A scientist who chooses to see a sand dune as a discrete multiplicity could decide to take a sample of sand for study, which, because of the homogeneity of the sand dune, would yield valid information about the whole sand dune.

In contrast, considering multiplicities as continuous implies that multiplicities are heterogeneous and not countable (Deleuze 1988). A continuous multiplicity changes in nature when divided because the elements of the multiplicity influence each other and cannot be unfolded without destroying its essence. Continuous multiplicities are subjective and allow different interpretations in parallel. When taking a continuous multiplicity perspective, understanding the whole requires a holistic view rather than a focus on individual elements. A 
scientist who chooses to see a sand dune as a continuous multiplicity could decide to study the entire sand dune, because the collective characteristics of the grains of sand (and thus the sand dune) may be different from the characteristics of individual grains of sand. In other words, this perspective suggests that the properties of the whole emerge from the interactions between the parts (DeLanda 2006).

Marketing literature on stakeholders has predominantly treated stakeholder networks as discrete multiplicities. Empirical work has mainly focused on dyadic relationships with specific stakeholders (Hult et al. 2011). The expectations of various stakeholders are considered independent from each other and addressed sequentially. In this perspective, the stakeholder network is the sum of all dyadic relationships, assuming that the stakeholder network can be understood by breaking it down to individual stakeholder relationships. In contrast, this paper argues that viewing stakeholder networks as continuous multiplicities constitutes the foundation of stakeholder marketing and provides more guidance on how to deal with the interrelatedness of stakeholders. Table 1 outlines three major differences between a traditional marketing perspective (viewing a stakeholder network as a discrete multiplicity) and a stakeholder marketing perspective (viewing a stakeholder network as a continuous multiplicity).

First, treating stakeholder networks as continuous multiplicities (as opposed to discrete multiplicities) changes how firms view and address stakeholder interests. Both the traditional marketing perspective and stakeholder marketing perspective acknowledge that a firm faces heterogeneous and often divergent interests of multiple stakeholders (Ingenbleek and Immink 2010; Lewin et al. 2011; Maignan and Ferrell 2004). However, while traditional marketing tends to deal with these interests one by one as if they were independent, stakeholder marketing views them as interrelated. In line with social network theory, stakeholder marketing recognizes that stakeholders interact directly or indirectly with each other (Rowley 1997; Neville and Menguc 2006; Shipilov and Li 2012) and that addressing a specific stakeholder's needs

Table 1 Overview of differences between traditional marketing perspective and stakeholder marketing perspective

Traditional marketing perspective Stakeholder marketing perspective

Stakeholder networks are viewed as Stakeholder networks are viewed as discrete multiplicities:

- The interests of stakeholders are viewed as independent

continuous multiplicities:

- Value perceptions of stakeholders are viewed as differing in importance, with customers taking primacy

- The interests of stakeholders are viewed as interrelated

- Acknowledging the value perceptions of multiple stakeholders is critical for success

- Value is viewed as created by the $\bullet$ Value is viewed as co-created with firm a multitude of stakeholders may simultaneously impact the relationship with other stakeholders. Firms employing stakeholder marketing do not "simply respond to each stakeholder individually but rather to an interaction of the multiple influences from the entire stakeholder set" (Garriga 2009, p. 623). A simplified comparison of Sony and Amazon's launch of their e-book readers (see Adner 2012) illustrates this point. While Sony recognized publishers as stakeholders, it focused on addressing consumer interests and failed to realize that consumer interests are not independent from publisher interests. In contrast, Amazon realized that publishers were reluctant to make content available for e-readers because they feared illegal copying and distribution. Therefore Amazon decided content on its e-reader could not be printed or shared, even though printing and sharing content would present a benefit for consumers. As a consequence, publishers were more willing to provide content for Amazon's e-reader, allowing Amazon to create more value for all stakeholders than Sony.

Second, traditional marketing primarily focuses on the value perceptions of one or two important stakeholders: customers and - to a lesser extent-distributors (e.g., Jones and Ritz 1991; Siguaw et al. 1998). Rooting back to Drucker (1954) and Levitt (1960), the marketing concept has put the customer at the center of business which has led to the value perception of customers taking primacy over other stakeholders' value perceptions. In traditional marketing, the focus on customers could be justified by the argument that customers are the only stakeholder group that generates revenues. However, customers are not always the revenue-generating stakeholder. For example, a television channel may provide entertainment without receiving money from customers if a third party is willing to advertise products on the channel (Bagozzi 1975). Stakeholder marketing takes the view that generation of revenues depends on other stakeholders and thus acknowledges that multiple stakeholders may be critical for success. Hence, customers are not necessarily considered as the single most important stakeholder group (Hult et al. 2011): the value perceptions of multiple stakeholders must be taken into account. In terms of multiplicity theory, stakeholder marketing leaves room for multiple interpretations of value in parallel. For example, Amazon understood that publishers were as important for the success of its e-reader as consumers and accepted that the publishers' concept of value (a product that limits illegal copying) is at least as important as the consumers' concept of value (a product that allows effortless copying).

Third, in traditional marketing value is created by the firm offering something of value to the customer. Vargo and Lusch (2004) introduced the service-dominant (SD) logic, arguing that value is co-created by the firm and its customers. More recent contributions to SD logic acknowledge that value is cocreated not only with customers, but with a multitude of stakeholders (Vargo and Lusch 2008; Vargo 2011; Lusch and 
Webster 2011). The value creation process is not confined to the firm, but takes place throughout the stakeholder network. In terms of multiplicity theory, stakeholder marketing sees the firm and its stakeholders as interpenetrating. This suggests that studying the value creation process as entirely under control of a firm (implied by traditional marketing) yields an imperfect understanding of how value is created. Stakeholder marketing, on the other hand, acknowledges that value co-creation occurs with a multitude of stakeholders and that value creation cannot be understood accurately by focusing on one stakeholder in isolation. For example, Amazon understood that it is not just the e-reader but also the content from the publishers that creates value. Thus, Amazon realized that value co-creation with consumers cannot be separated from value co-creation with publishers.

These three differences between traditional marketing and stakeholder marketing show that stakeholder marketing constitutes a fundamentally different perspective on stakeholder networks. More formally we present our first premise:

P1: The foundation of stakeholder marketing consists of viewing stakeholder networks as continuous multiplicities instead of discrete multiplicities.

We argue that this fundamentally different perspective provides a better understanding of marketing practice in many industries. More specifically, we observe three transitions in marketing practice that make the traditional perspective on stakeholder networks increasingly inappropriate and propose new capabilities to deal with these transitions. Table 2 outlines the three transitions: (1) complex value exchange is replacing dyadic value exchange; (2) the tension between stakeholder interests becomes explicit rather than implicit; and (3) as each stakeholder has its share in value creation, the control over marketing activities, which used to be centralized in the firm, is becoming dispersed across stakeholders. The more marketing practice is characterized by these three separate but interrelated transitions, the more firms need to view their stakeholder network as a continuous multiplicity and the more they need to develop new capabilities. In the following, we elaborate on these three transitions and the capabilities that are required for dealing with these transitions.

\section{Transitions and required capabilities}

Transition 1: from dyadic to complex exchange

In some stakeholder networks exchange may be essentially dyadic, as one actor gives up value to be received by another actor. In such situations, viewing stakeholder networks as discrete multiplicities is likely to provide an accurate picture because the interests on each side of the dyad do not depend on other stakeholders. However, in more and more stakeholder networks exchange relationships exist despite the fact that one actor receives less value than it gives up. Such imbalance in an exchange relationship may exist because value generated in relationships with other stakeholders indirectly balances the value in a system of complex exchange (Bagozzi 1975).

Complex exchange is one of the central concepts of social network theory (Emerson 1981; Granovetter 1985). Social network theory is particularly helpful to "examine characteristics of entire stakeholder structures and their impact on organizations' behavior, rather than individual stakeholder influences" (Rowley 1997, p. 887). It explicitly takes the

Table 2 Transitions in marketing practice and required capabilities

\begin{tabular}{|c|c|c|}
\hline & Associated with traditional marketing & Associated with stakeholder marketing \\
\hline \multicolumn{3}{|l|}{ Transition 1} \\
\hline Type of value exchange & Dyadic & Complex \\
\hline Required capability & $\begin{array}{l}\text { Relational thinking } \\
\text { (Understanding how to build and maintain } \\
\text { relationships with customers) }\end{array}$ & $\begin{array}{l}\text { Systems thinking } \\
\text { (Understanding the whole stakeholder } \\
\text { value system) }\end{array}$ \\
\hline \multicolumn{3}{|l|}{ Transition 2} \\
\hline Tension & Implicit & Explicit \\
\hline Required capability & $\begin{array}{l}\text { Logical thinking } \\
\text { (Following formal logic by adopting one } \\
\text { perspective, often the customer's) }\end{array}$ & $\begin{array}{l}\text { Paradoxical thinking } \\
\text { (Accepting and learning from tension } \\
\text { between stakeholder interests) }\end{array}$ \\
\hline \multicolumn{3}{|l|}{ Transition 3} \\
\hline Control & Centralized & Dispersed \\
\hline Required capability & $\begin{array}{l}\text { Responsive thinking } \\
\text { (Responding to the needs of stakeholders, mostly } \\
\text { customers, while remaining in control over } \\
\text { marketing decision making) }\end{array}$ & $\begin{array}{l}\text { Democratic thinking } \\
\text { (Sharing control over marketing } \\
\text { decisions with a multitude of } \\
\text { stakeholders) }\end{array}$ \\
\hline
\end{tabular}


interrelatedness of the nodes (focal firm and its stakeholders) into account. As such, it has been an inspiration for researchers of the Industrial Marketing and Purchasing group (e.g., Anderson et al. 1994) and other researchers of business networks (e.g., Bagozzi 1975; Iacobbuci 1996).

Based on insights from network literature, we define complexity of the value exchange as the degree to which firmstakeholder exchange relationships in the firm's stakeholder network influence or require the support of other stakeholders. That is, in stakeholder networks with high complexity of value exchange more stakeholders are required to achieve balance in terms of value than in stakeholder networks with low complexity of value exchange. In situations of high complexity of value exchange, viewing the stakeholder network one dyad at a time (as a discrete multiplicity) does not yield an accurate understanding of how the treatment of one stakeholder group impacts the exchange relationships with others. In such cases, a stakeholder marketing perspective (viewing a stakeholder network as a continuous multiplicity) provides a better understanding because it recognizes that the interests of stakeholders are interrelated. Thus, we posit that stakeholder networks vary in the degree of complexity of value exchange and that these stakeholder networks require a different perspective on marketing. More formally, our second premise is:

P2: Stakeholder marketing provides a better understanding of stakeholder networks with high complexity of value exchange, which is the degree to which firm-stakeholder exchange relationships in the firm's stakeholder network influence or require the support of other stakeholders.

More and more firms are facing stakeholder networks that are characterized by complex exchange rather than dyadic exchange. To illustrate this transition, consider SOSChildren's Villages, one of the leading childcare NGOs in the world. When SOS-Children's Villages needed to renovate the roofs in its oldest village at Imst, Austria, it did not have the money to buy the required tiles from tile manufacturer Bramac, which would constitute dyadic exchange (Fig. 1a). Perceiving the stakeholder network as a continuous multiplicity, other options become available (Fig. 1b). By organizing an event that would make the Guinness Book of Records (an attempt to renovate the roofs of 16 houses in $48 \mathrm{~h}$ ), SOSChildren's Villages made sure that the press found it sufficiently newsworthy to extensively cover the event (Jolibert et al. 2012). This coverage provided SOS-Children's Villages with an attractive proposal to approach Bramac to provide the tiles for free. Bramac received reputational benefits from the news coverage of the event by the media in return for free tiles for SOS-Children's Villages. None of the three dyadic relationships between the three parties involved in this stakeholder value system was balanced. However, by addressing the needs of the media and Bramac simultaneously, SOS-Children's Villages used its brand equity to create, via the media involved, enough value for Bramac to secure access to otherwise costly resources (the tiles).

Apple's mobile phone strategy provides another example of complex exchange (Fig. 1c): consumers paid above average prices for the device because, on top of other equityenhancing benefits, they had access to a large number of applications they could obtain for free or at low prices from Apple's app store. Apple, in turn, provided the developers with a retail platform reaching millions of consumers. As in the example above, none of the direct relationships was balanced, but each party received value through the integration of a third party in the exchange relationships. Figure $1 \mathrm{~d}$ shows an even more complex system, indicating that pharmaceutical companies need to take into account at least five different stakeholders when launching a drug.

To deal with the transition from dyadic to complex exchange, firms require a new capability. In traditional marketing, firms benefit from relational thinking, understanding how to build and maintain relationships with customers (Day 1994). In doing so, firms ignore the wider stakeholder value system. When faced with complex exchange, firms need to understand the indirect nature of value creation. Taking into account all stakeholders and their interrelationships helps firms to better understand how to deal with complex value exchange (Bhattacharya and Korschun 2008; Frow and Payne 2011; Layton 2007). This insight dovetails with the literature on business ecosystems (Adner 2012), co-opetition (Brandenburger and Nalebuff 1997), and organizational learning (Senge 1990) that emphasize the importance of focusing on the whole rather than the parts. However, dealing with complex value exchange is difficult (Senge 1990) and requires systems thinking, the capability of understanding the whole stakeholder value system. Systems thinking starts with identifying all stakeholders within the system. Stakeholder theory provides several tools that firms can use to identify stakeholders, the most well-known being the stakeholder power grid by Mitchell et al. (1997), which maps stakeholder importance along dimensions of legitimacy, power, and urgency. Systems thinking also includes understanding the structure of the system, i.e., how the stakeholders are linked to each other. Firms may gain such an understanding by using social network analysis (Wasserman and Faust 1994), value blueprints (Adner 2012), or agent-based modeling (Gilbert 2008). These tools provide firms insight in who influences whom in what way and who depends on whom, thus providing a better understanding of the stakeholder value system and how to operate in it. Hence, our third premise:

P3: A central capability of stakeholder marketing is systems thinking, which is the degree to which the firm is capable of understanding the whole stakeholder value system. 
Fig. 1 Examples of dyadic and complex exchange

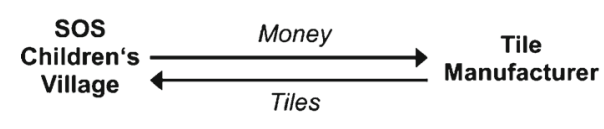

A: dyadic exchange at SOS Children's Village

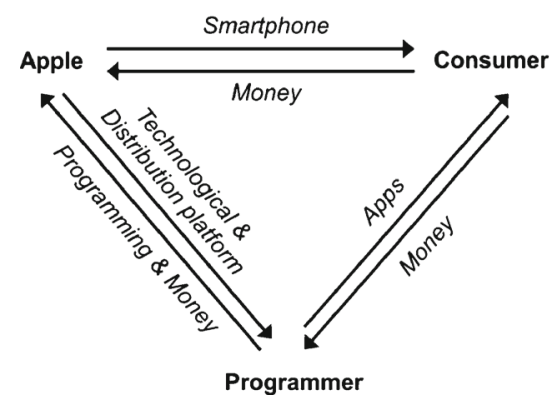

C: complex exchange at Apple

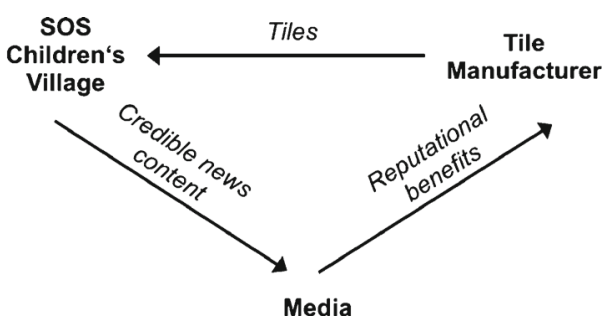

B: complex exchange at SOS Children's Village

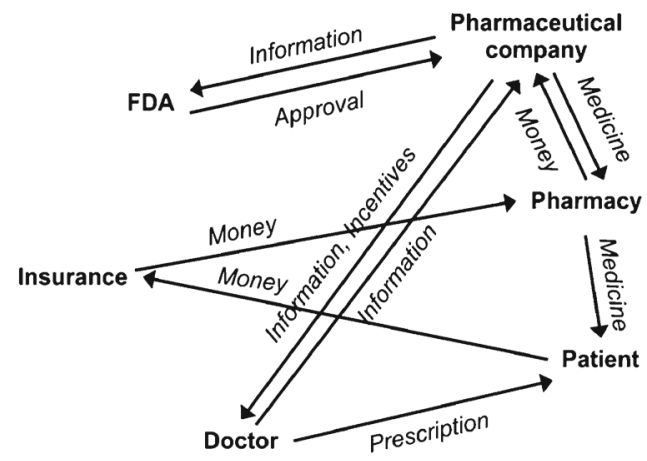

D: complex exchange at a pharmaceutical company
Transition 2: from implicit to explicit tension

Different stakeholders have different backgrounds, norms, and expectations about what a firm should do. They have different interests and, as a result, stakeholder networks are likely to be characterized by tension (Oliver 1991; Wood and Jones 1995; Neville and Menguc 2006). Stakeholder networks differ in the degree to which these tensions are explicit. We define the explicitness of tension as the degree to which multiple stakeholders in the firm's stakeholder network express opposing interests. Traditionally, many stakeholders did not have the opportunity to organize themselves and make themselves heard. As a result, the tension between stakeholder interests, while present in the stakeholder network, remained implicit. In such situations, stakeholder networks can be accurately viewed as discrete multiplicities; the interests of stakeholders can be understood one at a time and dealt with by prioritizing stakeholders. As the tensions were not directly expressed and did not emerge above the surface, marketing managers could prioritize customers and focus on their interests without having to deal with the tension between customer interests and the interests of other stakeholders.

Today, stakeholders have better access to information about how a firm affects their interests (Laszlo et al. 2005). Armed with this information and aided by technological developments, stakeholders have started to organize themselves and make themselves heard. As a result, a larger variety of stakeholder interests has come to the surface, to such an extent that they cannot be ignored anymore. In other words, in many stakeholder networks the tension between stakeholder interests has become more explicit. In situations of explicit tension between stakeholder interests, using a traditional marketing perspective (i.e., viewing stakeholder networks as discrete multiplicities) denies the fact that stakeholders voice conflicting interests, which reflect different value perceptions. Traditional marketing isolates one stakeholder group, customers, and posits that the interests and value perceptions of this stakeholder group take primacy (Drucker 1954). By prioritizing one stakeholder group, the tension between the interests of stakeholders is downplayed or ignored.

In contrast, by viewing stakeholder networks as continuous multiplicities the stakeholder marketing perspective acknowledges that stakeholders have opposing interests (and thus different perceptions of value). In such situations of explicit tension where multiple stakeholders have organized themselves and make themselves heard, it is difficult to ignore or downplay the value perceptions of these stakeholders that are needed for success. Therefore, a perspective is needed that recognizes the importance of the value perceptions of multiple stakeholders, a perspective that leaves room for multiple interpretations of value in parallel. In other words, the transition from implicit to explicit tension requires a shift in perspective from traditional marketing to stakeholder marketing. More formally, our fourth premise is:

P4: Stakeholder marketing provides a better understanding of stakeholder networks with high explicitness of tension, which is the degree to which multiple stakeholders in the firm's stakeholder network express opposing interests. 
Tension between stakeholder interests is common in many stakeholder networks. The exploitation of shale-embedded natural gas, for instance, involves many, often conflicting, stakeholder interests (Lewin et al. 2011): oil companies seek the profits of fossil fuels, consumers want lower energy prices, governments want to limit the dependence on imported fossil fuels, water companies want to protect their fresh ground water supply, mineral rights owners seek revenues from natural gas deposits, neighboring property owners fear a loss of value of their houses, and environmental NGOs want to protect nature. As another example of tension within a marketing system, tobacco firms all over the world are confronted with anti-smoking groups and governments that demand health warnings messages on the packaging of their cigarettes. In some countries law requires them to show pictures illustrating smoking-related health risks, creating tension with customers who do not want to be continuously reminded of their dangerous habit. As an example on a smaller scale, a manufacturer of ecological cleaning products, was confronted with animal rights organizations that opposed animal testing during the product development process of a new detergent. However, this stakeholder issue turned out to be incompatible with the requirements of some governments to test new ingredients on animals to ensure customer safety (Driessen and Hillebrand 2013).

Firms deal with tensions in several ways. One way is to use logical (or convergent) thinking to arrive at one single solution to a problem (Westenholz 1993). Traditional marketing draws on this line of reasoning by ignoring or suppressing tension and focusing on customer issues as the single most important criterion for solving problems. By choosing one side over the other, tensions are dealt with by assuming that problems can be resolved by following strict rules of investigation and sticking to "one grand theory," which ultimately should result in one solution (Westenholz 1993). In other words, there is room for only one "truth," which, because of the notion of customer primacy in traditional marketing, is often the customer's points of view.

Paradox theory (Poole and Van de Ven 1989; Lewis 2000; Smith and Lewis 2011) offers "an alternative approach to tensions, exploring how organizations can attend to competing demands simultaneously" (Smith and Lewis 2011, p. 381). Rather than drawing on logical thinking, paradox theory draws on dialectic theory (with its roots going back as far as early Greek and Chinese philosophy) suggesting that opposing forces may coexist (Lewis 2000). Paradox theory suggests that the interests of various stakeholders and resulting tension between them should be accepted, meaning that a firm must acknowledge multiple "truths" and that there is not necessarily a simple solution (Westenholz 1993; Smith and Lewis 2011). Paradox theory even suggests that tension provides an opportunity to learn, as "paradox management entails exploring, rather than suppressing, tensions" (Lewis 2000, p. 764). In the context of stakeholder marketing, exploring tensions entails taking all stakeholder interests seriously. Exploring tensions stimulates seeing things from different and multiple angles, thus changing the mental models a firm holds and helping "to discover new links between opposing forces" (Vince and Broussine 1996, p. 4). This is supported by studies that show that some successful firms actively seek tensions to improve decision making (Eisenhardt et al. 1997; Norman et al. 2004).

Stakeholder marketing thus requires paradoxical thinking, defined as a capability to accept and learn from the tension between stakeholder interests, rather than to ignore or suppress the tension. Paradoxical thinking requires a firm to have the cultures, structures, and processes to seek and integrate conflicting information (Smith and Lewis 2011). However, embracing tension is difficult, because people tend to prefer consistency in their beliefs and behaviors (Cialdini et al. 1995). The challenge for firms is to stimulate individuals in the firm (and external stakeholders) to overcome this desire for consistency and deal with the tensions that are inherent to stakeholder networks. Paradoxical thinking requires a firm to have the ability to avoid negative emotional responses to the tensions inherent with viewing stakeholder networks as continuous multiplicities, to remain calm and even in the face of tensions (Huy 1999). Such evenness limits anxiety spurred by tension, reduces defensive responses, and increases openness for critical reflection (Smith and Lewis 2011). In line with insights from strategic decision making (Amason 1996), we suggest that by embracing stakeholder tension, firms become more receptive to new ideas, obtain a deeper understanding of opposing viewpoints, and question longheld assumptions, which results in better decisions that are understood and accepted by stakeholders. Rather than avoiding the tension, firms that think paradoxically constantly re-examine the various stakeholder interests and the tension between them, which stimulates creativity and learning (Leonard-Barton 1995).

This does not imply that learning always results in a solution that fully meets the interests of all stakeholders. Rather, learning here refers to engaging in a stakeholder dialogue where all stakeholders reflect on the tension to reach a joint solution that may not be perfect to all, but where all stakeholders still perceive some benefit. Such "negotiating" (Alderson 1957) requires firms to be able to carefully listen to stakeholders and explain to stakeholders that there might not be a solution that fully meets all stakeholder interests. By making all stakeholders understand and acknowledge the interests of each other, a firm (in dialogue with the stakeholders) tries to reach a creative outcome where all stakeholders "are genuinely better off than they were before" (Alderson 1957, p. 136).

Stakeholder marketing thus includes taking stakeholder interests seriously and accepting the resulting tension between them, implying that paradoxical thinking is required. This leads to the following premise: 
P5: A central capability of stakeholder marketing is paradoxical thinking, which is the degree to which the firm is capable of accepting and learning from tension between stakeholder interests.

\section{Transition 3: from centralized to dispersed control}

When value is created by a single firm, the control over marketing decisions is centralized in that firm. In such situations, viewing stakeholder networks as discrete multiplicities is likely to present a realistic picture: the firm and its stakeholders are considered separate entities that respond to each other. However, in many stakeholder networks "no single firm can provide the total co-creation experience. Often, a network of firms must work together to provide a unique co-creation experience" (Prahalad 2004, p. 23). In other words, firms are embedded in business networks where multiple stakeholders are involved in the value creation process (Adner 2012; Anderson et al. 1994). When stakeholders are part of the value creation process, they gain more influence on the value created. In such stakeholder networks control over marketing decisions is more dispersed. We define dispersion of control as the degree to which stakeholders in the firm's stakeholder network are able to control marketing decision making.

In stakeholder networks with a high dispersion of control the boundaries between the firm and its stakeholders becomes blurred (Ashkenas 1999). As multiple stakeholders are empowered (either by the firm itself or by external developments such as technological innovations) the decision making unit extends outside the firm. Firms in such situations should recognize that they no longer have full control over marketing decision making. For example, Harley-Davidson "acknowledged the community as the rightful owner of the brand" (Fournier and Lee 2009, p. 106). In other words, in these stakeholder networks, the firm and its stakeholders are interpenetrated. As a result, in such situations, viewing stakeholder networks as continuous multiplicities is more accurate. In this respect the stakeholder marketing perspective follows recent developments in SD logic suggesting that co-creation relationships may not be limited to customers only, but could include other stakeholders as well (Vargo 2011; Lusch and Webster 2011; Frow and Payne 2011). This leads to the following premise:

P6: Stakeholder marketing provides a better understanding of stakeholder networks with high dispersion of control, which is the degree to which stakeholders in the firm's stakeholder network are able to control marketing decision making.

Dispersion of control can be observed across a variety of marketing decisions, such as branding, product specifications, distribution, and advertising. Ben \& Jerry's, a Unilever subsidiary, has a board of directors with representatives of NGOs, customers and Unilever managers that is empowered to protect and defend Ben \& Jerry's brand equity, integrity, and product quality. Volkswagen felt forced to change product specifications in 2013, after Greenpeace had waged a long battle while mobilizing over half a million supporters in demand of more efficient cars and lower car emissions (Greenpeace 2013). Starbucks uses a virtual dialogue with stakeholders to generate ideas, covering issues as product innovation, service improvements, and social responsibility (Chakravorti 2010). In general, a greater and more diverse set of stakeholders has gained control over a variety of marketing decisions (Chakravorti 2010; Day 2011).

This move towards dispersed control calls for a new capability. Whereas traditional marketing requires a "responsive thinking" capability, stakeholder marketing requires a "democratic thinking" capability. Responsive thinking refers to the ability of a firm to understand how to respond to the needs of its stakeholders (mostly customers), while remaining in control over marketing decision making. Thus, in traditional marketing marketers rule as 'enlightened despots' in an autocratic manner. Democratic thinking on the other hand refers to the ability to share control over marketing decisions with a multitude of stakeholders.

Democracy theory (Dahl 1991) provides insight in possible arrangements for sharing control with stakeholders. Part of democratic thinking is understanding which issues to subject to the democratic process (Dahl 1991). Although we have observed a dispersion of control across a variety of marketing decisions, firms may be unwilling or unable to extend this shared control to all marketing decisions. In addition, some judgment is involved in determining which stakeholders hold a legitimate claim and thus should be involved. This is similar to what is known in political science as the "problem of inclusion," which deals with the issue whether some individuals (e.g., children) can be rightfully excluded from democracy (Dahl 1991). If stakeholder networks are seen as continuous multiplicities this implies that shared control cannot be limited to a single stakeholder, because a multitude of interrelated stakeholders partakes in value co-creation. This has implications for the set of stakeholders that a firm may want to include in a democratic arrangement. Also, to find a procedure that weighs the votes of each stakeholder equally to the legitimacy of their stake may be a great challenge, especially given that some stakeholders are not numerous but still hold a legitimate stake (Harrison and Freeman 2004). Although dispersion of control across stakeholders implies that stakeholders are participating, it may be a challenge to create opportunities for disenfranchised stakeholders to effectively participate (Dahl 1991). For example, while a clothing retailer may consider employees working in overseas sweatshops run by their suppliers as legitimate stakeholders, allowing them to place issues 
on the agenda may be cumbersome. Sharing control also implies some transparency of information. Stakeholders should have "adequate and equal opportunities" to acquire an understanding of the decision at hand and its potential consequences (Dahl 1991, p. 112). To exert control over marketing decisions without great harm to the system, stakeholders may need to be educated about the consequences of their decisions for other stakeholders. For example, non-profit conference organizer TED explains to the independent members of the TEDx community what the consequences would be of inviting low quality speakers, stimulates a dialogue on the shared objectives of the TEDx community, and helps members by giving guidelines on how to contribute (Merchant 2013). Transparency does not mean that all information needs be to shared: part of the capability is to understand which information is required by stakeholders to co-create value. Researchers have suggested that the capability of knowing where and how to open up is crucial in situations of co-creation (Balka et al. 2013; Merchant 2013).

In short, there are several arrangements for value cocreation that firms need to understand and set up when stakeholder networks are characterized by dispersed control. We suggest that through trial and error firms develop an understanding which level of stakeholder democracy is needed, because too much democracy may not be appropriate (Harrison and Freeman 2004). We argue that, by accepting that stakeholder networks are continuous multiplicities, firms share control with stakeholders, and are in need of a better understanding of democratic arrangements. More formally, our final premise is:

P7: A central capability of stakeholder marketing is democratic thinking, which is the degree to which the firm is capable of sharing control over marketing decisions with a multitude of stakeholders.

\section{Discussion}

The stakeholder marketing perspective and the associated capabilities have implications for firm performance, marketing theory, empirical research, and practice. We discuss each of these implications below.

\section{Implications for firm performance}

Having conceptualized the three central capabilities of stakeholder marketing, this paper provides avenues for further research on the consequences for firm performance of these capabilities. Stakeholder marketing capabilities are unlikely to have a short-term and direct effect on traditional performance measures, such as profits, sales, or market share. Instead, based on literature on stakeholder relations (Maignan and Ferrell 2004; Bosse et al. 2009; Choi and Wang 2009; Surroca et al. 2010), we expect their impact to be long-term and indirect. More specifically, stakeholder marketing capabilities are likely to lead to strong stakeholder relationships. The strength of stakeholder relationships may be manifested by stakeholders' identification with the firm (Maignan and Ferrell 2004), a good reputation among stakeholders (Surroca et al. 2010), and a high degree of fairness of the firm as perceived by the stakeholders (Bosse et al. 2009). Systems thinking is likely to generate stronger stakeholder relationships, because understanding the whole stakeholder value system lies at the root of building networks for shared value creation that give stakeholders a sense of identification with the firm (and the rest of the network). Similarly, paradoxical thinking may increase the perceived fairness of the firm in the eyes of the stakeholders because paradoxical thinking implies taking all stakeholder issues seriously, even when they conflict, in an attempt to let all stakeholder benefit. Democratic thinking is also likely to improve stakeholder relationships: firms that share control with multiple stakeholders are likely to be perceived as more fair by their stakeholders. Also, such firms are likely to be better at involving stakeholders, which stimulates the stakeholders' identification with the firm.

Stakeholder relationships constitute a source of competitive advantage (Surroca et al. 2010) that not only generate financial rents but also protect the firm against hostility (such as product harm crises) and contribute to firm survival (Choi and Wang 2009). More specifically, strong stakeholder relationships reflect the willingness of stakeholders to support the firm with their resources (Maignan and Ferrell 2004). For example, firms with strong stakeholder relationships are likely to have employees that are willing to work harder, have customers that are willing to pay premium prices, obtain endorsements from NGOs, and receive knowledge from suppliers (Choi and Wang 2009). Thus, while stakeholder marketing capabilities may not have "hard" short-term performance consequences, we do expect that they have important long-term performance consequences.

Implications for marketing theory

We offer five implications for marketing theory. First, the paper demonstrates that stakeholder marketing goes beyond acknowledging that firms have more stakeholder groups than the one marketing academics and practitioners are usually concerned with (the customers). By viewing stakeholder networks as continuous multiplicities, we show that stakeholder marketing not only consists of employing specific stakeholder marketing activities (Hult et al. 2011) but also requires a fundamentally different way of thinking about marketing in its environment. Our paper thus answers recent calls for a more 
holistic perspective on markets and marketing, claiming that "marketers would need to understand the whole ecosystem" (Mele et al. 2015). Traditional marketing has mainly focused on the level of the individual firm (marketing management) or the customer (consumer behavior). In stakeholder marketing, on the other hand, "the unit of analysis is the firm along with its network of stakeholders" (Hult et al. 2011, p. 48; see also Preston and Donaldson 1999). It links the micro level (the firm) to the macro level (the stakeholder network) and inherently implies a systems approach, which has been present in recent marketing literature only as an undercurrent. Such a perspective on marketing offers a much richer and more realistic picture of what many marketing managers are facing in today's turbulent world. In doing so, our continuous multiplicity perspective provides a better understanding of the nature of value creation, a concept lying at the core of the marketing discipline.

Second, the stakeholder marketing perspective as described in this paper builds on and enriches several streams within the relational perspective on marketing. "Relationship marketing" was coined by Berry in 1983 as the concept of attracting, retaining, and enhancing customer relationships (Berry 1995). It emerged as a perspective on marketing that moved beyond discrete events (Dwyer et al. 1987). Much of the attention in relationship marketing focused on constructs like trust, commitment, and loyalty as mechanisms of relationships (see Palmatier et al. 2006 for an overview). Relationship marketing has been shown to be of strategic importance for firms in the customer relationship management literature (Reinartz et al. 2004; Payne and Frow 2005). In a supply chain context, research has yielded insights in the nature of relationships between firms (Cannon and Perreault 1999; Wathne and Heide 2004). In a business-to-business setting a network approach has been used to understand the embedded context of dyadic relationships (Anderson et al. 1994). Also in a business-to-business setting, personal relationships between boundary spanners of different firms have been shown to drive interfirm relationships (Haytko 2004). The SD logic has expanded the notion of relationships to also include cocreational elements (Vargo and Lusch 2004). Together these streams within relationship marketing literature provide a rich understanding of the mechanisms and implications of relationships. Several authors in relationship marketing have suggested that these insights may not only apply to customer relationships, but also to relationships with other stakeholders (Grönroos 1990; Berry 1995; Payne and Frow 2005). The contribution of our paper to the relational perspective on marketing is that it highlights the interdependence between multiple relationships with a diverse set of stakeholders.

The third implication of our paper for marketing theory is that it revitalizes insights from the systems perspective on marketing from the 1950s and furthers these insights by taking the complexities of networks seriously. Literature on systems in marketing (Alderson 1957; Fisk 1967; Layton 2007) has described the stakeholders in the market systems in which marketing takes place. However, these streams of literature seem to have been somewhat forgotten and have scarcely investigated the implications of viewing the stakeholder network as a continuous multiplicity.

The fourth implication of our paper for marketing theory is a contribution to the debate on whether managing stakeholder relationships should be part of marketing. Critics of stakeholder marketing may argue that managing the relationships with stakeholders other than customers is part of other business domains. However, in stakeholder networks that are characterized by complex exchange, explicit tensions and dispersed control, relationships with different stakeholders cannot be viewed in isolation. Value is created by and exchanged within the whole stakeholder network, which inherently constitutes a marketing issue (Bagozzi 1975; Jurgens et al. 2010). In other words, in many situations marketing has no choice but to accept the whole array of stakeholders as its domain. We do not claim that only marketing is responsible for stakeholder relationships. In fact, many other organizational entities and functions (including the CEO, the board and other functional units) might benefit from embracing a stakeholder mindset. But marketing may be a "natural" candidate to take the lead in moving the firm forward in the complex stakeholder network (Murray and Montanari 1986), as it is "outwardly focused" (Parmar et al. 2010; Sheth et al. 2011) with strong expertise on developing and maintaining value exchange relationships. By embracing the study of all value-creating relationships in the stakeholder network instead of focusing on the customer-firm dyad alone, marketing has an opportunity to reclaim areas of inquiry (such as supply chain management) to its agenda. This provides a perfect opportunity to elevate marketing as a field and revert "its march toward less relevance to the firm and less legitimacy in the eyes of society" (Webster and Lusch 2013, p. 390).

The final theoretical implication of our paper is that the principle of customer primacy (or customer centricity) that underlies most of marketing theory is challenged. Marketing theory has - explicitly or implicitly — made the customer the most important stakeholder group of the firm. This principle of customer primacy is firmly rooted into marketing thinking, as witnessed by this quote from Drucker (1954, p. 39) about marketing: "It is the whole business seen from the point of view of its final result, that is, from the customer's point of view." By emphasizing the fulfillment of customer needs, Levitt (1960) also puts the customer firmly in the middle of the marketing universe. Customer centricity has even been proposed as the core of intellectual inquiry in marketing (Deshpandé 1999) and has remained a common ground for many theoretical advances (e.g., Shah et al. 2006). The principle of customer centricity has rarely been challenged (see Gummesson (2008) for a notable exception). Instead, the 
stakeholder marketing perspective holds that customers cannot be viewed in separation of the rest of the stakeholder network and that the value perceptions and interests of other stakeholders may sometimes carry an equal or greater weight. Although challenging the notion of customer primacy may seem like a Copernican revolution, this paper does not mean to belittle the role of the customer as an important stakeholder group. Instead, this paper intends to argue that marketing is much more complex than its current customer-centric representation by marketing theory suggests. As such, our paper "reconsiders, redefines, and revitalizes [marketing's] intellectual domain" (Webster and Lusch 2013, p. 390).

Implications for empirical research

Our paper also has implications for empirical research in marketing. First, researchers should empirically investigate when and how stakeholder marketing materializes in practice and what the performance consequences are. As a first step in that direction, we provide potential data sources and operationalizations of the main research concepts (see Table 3). Several firms already embrace stakeholder marketing, some of which are very successful (Sisodia et al. 2007). Case research in firms that excel in stakeholder marketing as well as firms in complex and challenging stakeholder networks may be used to further operationalize stakeholder marketing capabilities: how do firms analyze stakeholder systems? How do firms deal with tensions? And how do they democratize their marketing decisions?

Second, empirical research may also help us better understand how stakeholder marketing can be implemented in firms. Such research may take a similar approach as the qualitative study on the implementation of market orientation by Gebhardt et al. (2006). It would be especially interesting to investigate which organizational structures and processes facilitate the implementation of stakeholder marketing. When firms move towards further integration of their stakeholders into their marketing decision making processes, they may want to adapt their organizational structures to facilitate the increased intensity and richness of the information that comes with more stakeholder integration (Driessen et al. 2013). Future studies could help shed light which organizational structures for stakeholder marketing are most successful.

Third, as dispersing control and experimenting with democratic arrangements gain more significance when adopting stakeholder marketing, the notion of fairness (or justice) becomes increasingly important. In settings with multiple and interrelated stakeholders, maximization of self-interest of the individual stakeholders is not optimal for the system of stakeholders as a whole. Therefore, stakeholders can be expected to optimize self-interest under constraints of fairness (Bosse et al. 2009). As a consequence, theories that include fairness are better equipped to explain behavior in contexts of dispersed control than existing theories of rational behavior (Bosse et al. 2009). We therefore call for more research using justice theory applied in the context of stakeholder networks. Fairness may be especially interesting not only because it relates to the discussion on the societal relevance of marketing (Ferrell and Ferrell 2008), but also because it is a relevant factor for the firm as stakeholder systems that are more fair are likely to form a more stable environment for the firm. If perceived justice by one of the stakeholders in the marketing system is too low, the marketing system may no longer be considered fair and may cease to create value to all stakeholders in the long run (Bosse et al. 2009).

Fourth, our paper claims that a systems perspective is pivotal for a better understanding of stakeholder marketing. Yet, marketing literature has paid little attention to stakeholder systems. Early ideas about market systems (e.g., Alderson 1957; Fisk 1967) have not made major inroads in current marketing literature. In line with Layton (2007) and Webster and Lusch (2013), we call for more research that takes a systemic perspective because it is important to "see more clearly how a single specific actor (e.g., a firm) can participate more effectively" (Vargo and Lusch 2011, p. 182). Methods that can deal with complex interactions between actors in a system, such as agent-based modeling, may be helpful here (Gilbert 2008).

\section{Implications for practice}

This paper suggests that marketing practice should develop three additional capabilities to deal with stakeholder networks that show transitions from dyadic to complex exchange, from implicit to explicit tension, and from centralized to dispersed control. We suggest that developing stakeholder marketing capabilities follows a process (see Fig. 2), much in line with the steps suggested by Day (2011).

The first step consists of diagnosing the gap between required and actual stakeholder marketing capabilities (see Fig. 2). Many firms are likely to have weak stakeholder marketing capabilities (as indicated by the dashed lines "actual" in Fig. 2). This is not much of a problem when a firm is facing a stakeholder network that is characterized by low levels of complex exchange, explicit tension and dispersion of control, because less systems thinking, paradoxical thinking, and democratic thinking is needed in such situations (as indicated by the solid lines "required" in Fig. 2). However, it is a problem for firms in stakeholder networks with high levels of complex exchange, explicit tension and dispersion of control. Such firms may be found in industries such as health care, pharmaceuticals, energy, public transport, media, agriculture, information technology and telecommunications. Firms viewing such stakeholder networks as discrete multiplicities are less likely to recognize that strong stakeholder marketing capabilities are required and as a result are more likely to have weak stakeholder marketing capabilities. In such situations firms are 
Table 3 Potential data sources and operationalizations of the main research concepts

\begin{tabular}{|c|c|c|}
\hline Main concept & Definition & Potential data source and operationalization \\
\hline \multicolumn{3}{|c|}{ Characteristics of stakeholder network } \\
\hline Complexity of value exchange & $\begin{array}{l}\text { Degree to which firm-stakeholder exchange } \\
\text { relationships in the firm's stakeholder network } \\
\text { influence or require the support of other } \\
\text { stakeholders }\end{array}$ & $\begin{array}{l}\text { - Interviews with industry experts or network analysis to } \\
\text { determine the number of stakeholders needed for exchange } \\
\text { within the focal industry } \\
\text { - Interviews with industry experts or network analysis to determine } \\
\text { the minimum number of exchange relationships in any business } \\
\text { model within the focal industry }\end{array}$ \\
\hline Explicitness of tension & $\begin{array}{l}\text { Degree to which multiple stakeholders in the firm's } \\
\text { stakeholder network express opposing interests }\end{array}$ & $\begin{array}{l}\text { - Content analysis on press articles to investigate the number and } \\
\text { intensity of conflicts between stakeholders in the focal industry } \\
\text { - Netnographic analysis to investigate the number and intensity } \\
\text { of opinions about the focal industry } \\
\text { - Opinion polls among multiple stakeholder groups to investigate } \\
\text { the number and intensity of concerns about the focal industry }\end{array}$ \\
\hline Dispersion of control & $\begin{array}{l}\text { Degree to which stakeholders in the firm's stakeholder } \\
\text { network are able to control marketing decision making }\end{array}$ & $\begin{array}{l}\text { - Interviews with managers to investigate the number of marketing } \\
\text { decisions where stakeholders have been involved } \\
\text { - Survey among managers to investigate the weight of the voice } \\
\text { of stakeholders in marketing decisions such as pricing, } \\
\text { innovation, and branding }\end{array}$ \\
\hline \multicolumn{3}{|l|}{ Stakeholder marketing capabilities } \\
\hline Systems thinking & $\begin{array}{l}\text { Degree to which the firm is capable of understanding } \\
\text { the whole stakeholder value system }\end{array}$ & $\begin{array}{l}\text { - Managerial interviews to investigate the managers' insight in the } \\
\text { role of all stakeholders in the business model } \\
\text { - Content analysis of corporate documents to examine the firm's use } \\
\text { of tools like social network analysis, value blueprints, and } \\
\text { agent-based modeling }\end{array}$ \\
\hline Paradoxical thinking & $\begin{array}{l}\text { Degree to which the firm is capable of accepting and } \\
\text { learning from tension between stakeholder interests }\end{array}$ & $\begin{array}{l}\text { - Managerial interviews to investigate managers inclination to } \\
\text { explore conflicts } \\
\text { - Interviews to investigate occurrence of groupthink (reversed) } \\
\text { - Survey with psychological measurements to investigate managers' } \\
\text { ability to see things from multiple angles, their emotional } \\
\text { evenness, and their preference for consistency (reversed) }\end{array}$ \\
\hline Democratic thinking & $\begin{array}{l}\text { Degree to which the firm is capable of sharing control } \\
\text { over marketing decisions with a multitude of } \\
\text { stakeholders }\end{array}$ & $\begin{array}{l}\text { - Archival analysis to determine the degree of experimentation on } \\
\text { co-creation (on issues like inclusiveness and transparency) and } \\
\text { monitoring the outcomes of the experiments } \\
\text { - Interviews with managers to determine the quality and } \\
\text { deliberation of decision making on sharing control with } \\
\text { stakeholders }\end{array}$ \\
\hline \multicolumn{3}{|l|}{ Firm performance } \\
\hline $\begin{array}{l}\text { Stakeholder relationship } \\
\text { strength }\end{array}$ & $\begin{array}{l}\text { Overall assessment of the relationship with the focal } \\
\text { firm by stakeholders }\end{array}$ & $\begin{array}{l}\text { - Surveys among stakeholders to examine organizational } \\
\text { identification, } \\
\text { firm reputation, perceived firm fairness } \\
\text { - Archival analysis of formal and observation of informal } \\
\text { firm-stakeholder interactions }\end{array}$ \\
\hline Stakeholder support & $\begin{array}{l}\text { Degree to which stakeholders are willing to provide } \\
\text { valuable resources to the firm }\end{array}$ & $\begin{array}{l}\text { - Surveys among stakeholders to examine willingness to work } \\
\text { harder (employees), willing to pay premium price (customers), } \\
\text { willingness to endorse, willingness to share knowledge }\end{array}$ \\
\hline
\end{tabular}

likely to enjoy the largest marginal gains from embracing stakeholder marketing. But even firms in less complex and dynamic environments (such as many firms in consumer packaged goods industries) face scrutiny from multiple stakeholders and may thus benefit from developing stakeholder marketing capabilities, albeit probably to a lesser degree. Managers can use the indicators suggested in Table 3 for the capabilities and for the characteristics of the stakeholder network to diagnose the gaps.

The second step of the stakeholder marketing capabilities development process involves prioritization of the required capabilities. To make the development of these capabilities more manageable we advise to compare the three gaps (actual versus required level of systems thinking, paradoxical thinking, and democratic thinking) with respect to their size and the urgency to close them. As developing stakeholder marketing capabilities is likely to be challenging, we suggest that managers focus on the most critical capability first. The most critical stakeholder marketing capability is determined by the size of the gap and the urgency of closing the gap. For example, if the stakeholder network is characterized by complex exchange, but not so much by explicit tension and control 
Fig. 2 Closing the stakeholder marketing capabilities gaps

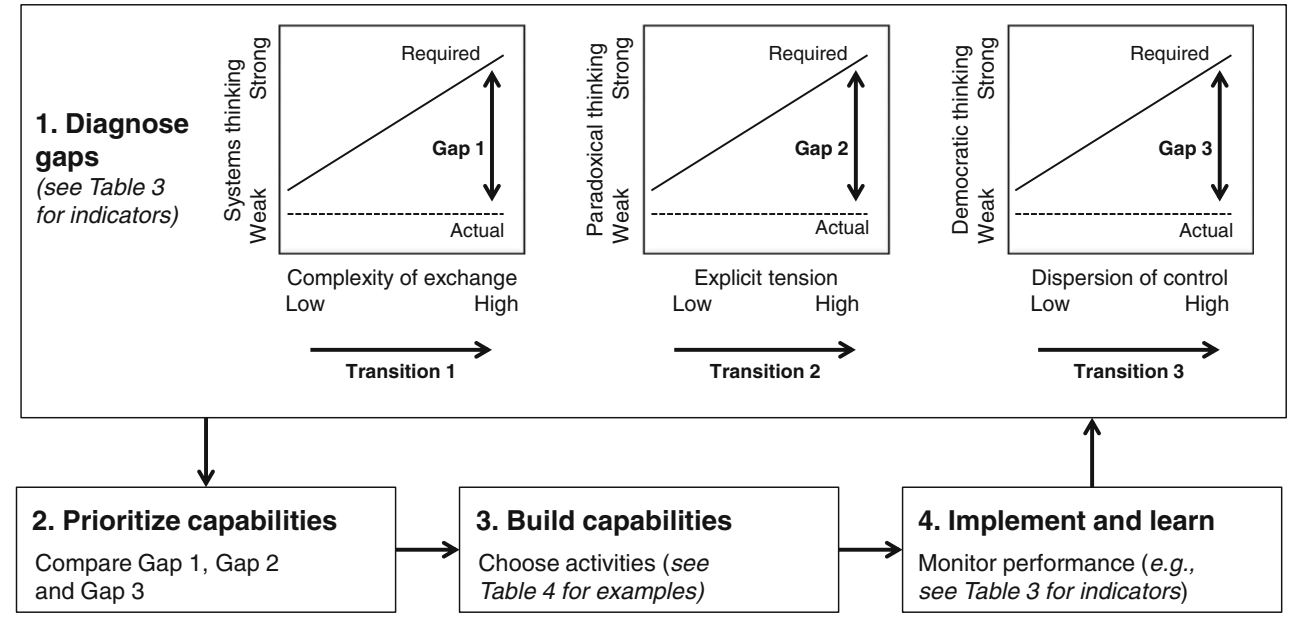

sharing, a firm should foremost strive to improve its systems thinking capabilities. If stakeholders that are crucial for value creation threaten to withdraw participation, improvement of the democratic thinking capability seems urgent. Such an evaluation needs to be made on a regular basis because both the stakeholder network and the developed stakeholder marketing capabilities are dynamic.

Step three constitutes the actual building of the capabilities. Table 4 outlines a set of exemplary actions that enhance the development of each capability. We do not claim this set to be exhaustive. In addition, the effectiveness of the suggestions offered here is a topic of further investigation. However, the table does illustrate the breadth of possible actions that managers may want to consider when starting to build stakeholder marketing capabilities.

The strategic management literature argues that a firm's structure needs to adjust to its strategy (e.g., Miles et al. 1978). Therefore, when building stakeholder marketing capabilities, firms are well-advised to consider how to organize for stakeholder marketing. For example, as an individual (or individuals from one organizational function) is likely to have insufficient exposure to the whole stakeholder network, crossfunctional teams (possibly even involving external stakeholders) may help firms to foster systems thinking. Crossfunctional teams are more likely to provide a comprehensive understanding of the relevant stakeholders, their interests, and relationships. Cross-functional teams provide the "bandwidth" (i.e., information processing capacity) that firms need when confronted with more, diverse and complex stakeholder issues (Driessen et al. 2013). Similarly, building paradoxical thinking may require installing stakeholder advocates within the firm, i.e., people with the designated role to keep stakeholder issues on the agenda and thus to ensure that tensions are not ignored (Driessen and Hillebrand 2013).

Firms that want to build stakeholder marketing capabilities may also want to adapt their recruiting efforts and reward systems. For example, to master paradoxical thinking, firms should strive to hire people that are sufficiently tolerant towards ambiguity and to reward employees that question assumptions and raise opposing views. Similarly, democratic thinking may be fostered by recruiting people that are not afraid to give up control (i.e., that score low on a desirability of control scale) and by rewarding employees based on the perceived justice among the various stakeholder groups.

Building stakeholder marketing capabilities may also require a firm to redesign the role of marketing professionals (including brand managers, product managers, and sales employees) and their typical tasks. Embracing stakeholder marketing means that marketing professionals are forced to adjust their customer-centric views (which were long regarded as defining marketing professionals). Irrespective of the focal task of marketing professionals - whether in sales, product marketing, service delivery, or brand management - the capability of systems thinking implies that they have to continuously monitor and map the stakeholder network when reflecting on past and future decisions. Paradoxical thinking implies that marketing professionals need to focus more on analyzing the tensions in the stakeholder network and negotiate between stakeholders. Doing so involves making stakeholders understand the trade-offs and explaining solutions to them especially when they do not receive what they initially wanted. To stimulate democratic thinking marketing professionals may need to focus on providing the conditions for co-creation of value by setting up the appropriate democratic arrangements. This may include making decisions about which stakeholders to include in specific decision making areas, which information to provide them with, and how to achieve a common purpose within the stakeholder network.

Managerial tools for each stakeholder marketing capability are plentiful, varying from network analysis and value blueprinting to enhance systems thinking to experimenting with ideation contests and online community empowerment to foster democratic thinking. Both firms and educational 
Table 4 Examples for building stakeholder marketing capabilities

\begin{tabular}{|c|c|c|c|}
\hline & Developing systems thinking & Developing paradoxical thinking & Developing democratic thinking \\
\hline $\begin{array}{l}\text { Organizational } \\
\text { structure }\end{array}$ & $\begin{array}{l}\text { Regular cross-functional team } \\
\text { meetings to update the actors, their } \\
\text { interests and relationships in the } \\
\text { stakeholder system }\end{array}$ & $\begin{array}{l}\text { Stakeholder advocates in central } \\
\text { positions in the organization to } \\
\text { keep issues of stakeholders on } \\
\text { the agenda }\end{array}$ & $\begin{array}{l}\text { Decision making boards that include } \\
\text { representatives from all } \\
\text { stakeholders for specific } \\
\text { marketing decisions }\end{array}$ \\
\hline Recruiting & $\begin{array}{l}\text { Hire employees that score high on } \\
\text { Analysis-Holism Scale }\end{array}$ & $\begin{array}{l}\text { Hire employees that score high } \\
\text { on Ambiguity Tolerance Scale }\end{array}$ & $\begin{array}{l}\text { Hire employees that score low on } \\
\text { Desirability of Control Scale }\end{array}$ \\
\hline Reward systems & $\begin{array}{l}\text { Reward employees based on the value } \\
\text { generated for the whole stakeholder } \\
\text { system }\end{array}$ & $\begin{array}{l}\text { Reward employees with } \\
\text { opposing views/who question } \\
\text { assumptions }\end{array}$ & $\begin{array}{l}\text { Reward employees that increase } \\
\text { perceived fairness within the } \\
\text { stakeholder network }\end{array}$ \\
\hline $\begin{array}{l}\text { Role of marketing } \\
\text { professional }\end{array}$ & $\begin{array}{l}\text { Monitor and map the stakeholder } \\
\text { network }\end{array}$ & $\begin{array}{l}\text { Analyze tension and negotiate } \\
\text { within the stakeholder network }\end{array}$ & $\begin{array}{l}\text { Set up arrangements that facilitate } \\
\text { and stimulate value co-creation } \\
\text { in the stakeholder network }\end{array}$ \\
\hline Tools & $\begin{array}{l}\text { Network analysis, stakeholder power } \\
\text { grid, value blueprints, agent-based } \\
\text { modeling }\end{array}$ & $\begin{array}{l}\text { Stakeholder checklists to increase } \\
\text { awareness for implications for } \\
\text { all stakeholders, stakeholder } \\
\text { dialogues, creativity } \\
\text { enhancement techniques }\end{array}$ & $\begin{array}{l}\text { Voting systems, ideation contests, } \\
\text { online community } \\
\text { empowerment, } \\
\text { transparent reporting }\end{array}$ \\
\hline
\end{tabular}

institutions should educate (future) marketing professionals in applying these tools.

The final and fourth step of the stakeholder marketing capabilities development process is to implement (i.e., actually use) the capabilities and observe in the stakeholder network how well they work. Doing so spurs a continuous learning process about stakeholder marketing capabilities. The performance measures suggested in Table 3 may provide a first indication of to what degree the new capabilities have helped the organization. It is important to recognize that closing the stakeholder marketing capability gap is likely to be a trial and error process (hence the feedback loop in Fig. 2).

\section{Conclusion: reclaiming marketing's territory}

As a business function, marketing has been losing influence in the boardroom (Verhoef and Leeflang 2009; Webster et al. 2005). This loss may be partly due to the inability of the marketing function to deal with modern-age complexities. Because of this inability, marketing's territory within businesses has often been reduced to tactical decision making. By adopting stakeholder marketing, marketers can again influence strategic decision making (Webster and Lusch 2013).

While the latest AMA definition of marketing includes stakeholders ("value for customers, clients, partners, and society at large"), marketing academics have not yet embraced this fully in their field of inquiry. As a result, the academic field of study has become unnecessarily limited in scope and influence. Marketing has in whole or in part conceded topics of study to other disciplines: supply chain issues to operations and logistics management, value creating strategies to strategic management, and service delivery to operations management (Lehmann 2005). By explicitly recognizing the role of multiple stakeholders in the creation of value, stakeholder marketing puts these topics firmly back into the marketing domain, which provides the marketing discipline the opportunity to reclaim its lost territory. Alderson (1957) already called for such a holistic perspective on marketing. This paper may be read as a call to reconnect to these historic roots as a way to revitalize the marketing discipline.

Acknowledgments The authors gratefully acknowledge the help of Hans Mühlbacher in developing the ideas presented in this article. Robert Lusch, Jaideep Prabhu, Edward Freeman, Vera Blazevic, Paul Ingenbleek, and Bas van der Linden provided insightful feedback on earlier versions of this article, as did seminar participants at RWTH Aachen University and Rotterdam School of Management, participants of the workshop on stakeholder branding at the University of Innsbruck, participants of the AMA Winter Conference, and participants of the special interest group meetings on stakeholder marketing at conferences of the European Marketing Academy.

Open Access This article is distributed under the terms of the Creative Commons Attribution License which permits any use, distribution, and reproduction in any medium, provided the original author(s) and the source are credited.

\section{References}

Adner, R. (2012). The wide lens; A new strategy for innovation. London: Penguin.

Alderson, W. (1957). Marketing behavior and executive action: A functionalist approach to marketing theory. Homewood: Irwin. 
Amason, A. C. (1996). Distinguishing the effects of functional and dysfunctional conflict on strategic decision making: resolving a paradox for top management teams. Academy of Management Journal, 39, $123-148$.

Anderson, J. C., Håkansson, H., \& Johanson, J. (1994). Dyadic business relationships within a business network context. Journal of Marketing, 58, 1-15.

Ashkenas, R. (1999). Creating the boundaryless organization. Business Horizons, 42, 5-10.

Bagozzi, R. P. (1975). Marketing as exchange. Journal of Marketing, 39, 32-39.

Balka, K., Raasch, C., \& Herstatt, C. (2013). The effect of selective openness on value creation in user innovation communities. Journal of Product Innovation Management, 31, 392-407.

Bergson, H. (1910). Time and free will. Kila: Kessinger Publishing.

Berry, L. L. (1995). Relationship marketing of services: growing interest, emerging perspectives. Journal of the Academy of Marketing Science, 23, 236-245.

Bhattacharya, C. B., \& Korschun, D. (2008). Stakeholder marketing: beyond the four Ps and the customer. Journal of Public Policy \& Marketing, 27, 113-116.

Bosse, D. A., Phillips, R. A., \& Harrison, J. S. (2009). Stakeholders, reciprocity, and firm performance. Strategic Management Journal, 30, 447-456.

Brandenburger, A. M., \& Nalebuff, B. J. (1997). Co-opetition. New York: Currency Doubleday.

Cannon, J. P., \& Perreault, W. D., Jr. (1999). Buyer-seller relationships in business markets. Journal of Marketing Research, 36, 439-460.

Chakravorti, B. (2010). Stakeholder marketing 2.0. Journal of Public Policy \& Marketing, 29, 97-102.

Choi, J., \& Wang, H. (2009). Stakeholder relations and the persistence of corporate financial performance. Strategic Management Journal, 30, 895-907.

Cialdini, R. B., Trost, M. R., \& Newsom, J. T. (1995). Preference for consistency: the development of a valid measure and the discovery of surprising behavioral implications. Journal of Personality and Social Psychology, 69, 318-328.

Clarkson, M. B. E. (1995). A stakeholder framework for analyzing and evaluating corporate social performance. Academy of Management Review, 20, 92-117.

Dahl, R. A. (1991). Democracy and its critics. New Haven: Yale University Press.

Day, G. S. (1994). The capabilities of market-driven organizations. Journal of Marketing, 58, 37-52.

Day, G. S. (2011). Closing the marketing capabilities gap. Journal of Marketing, 75, 183-195.

Day, G. S., \& Wensley, R. (1983). Marketing theory with a strategic orientation. Journal of Marketing, 47, 79-89.

DeLanda, M. (2006). A new philosophy of society; assemblage theory and social complexity. London: Continuum.

Deleuze, G. (1988). Bergsonism. New York: Zone Books.

Deshpandé, R. (1999). 'Foreseeing' marketing. Journal of Marketing, 63, 164-167.

Dhanaraj, C., \& Parkhe, A. (2006). Orchestrating innovation networks. Academy of Management Review, 31, 659-669.

Donaldson, T., \& Preston, L. E. (1995). The stakeholder theory of the corporation: Concepts, evidence, and implications. Academy of Management Review, 20, 65-91.

Driessen, P. H., \& Hillebrand, B. (2013). Integrating multiple stakeholder issues in new product development: an exploration. Journal of Product Innovation Management, 30, 364-379.

Driessen, P. H., Kok, R. A. W., \& Hillebrand, B. (2013). Mechanisms for stakeholder integration: bringing virtual stakeholder dialogue into organizations. Journal of Business Research, 66, 1465-1472.

Drucker, P. F. (1954). The practice of management. New York: Harper \& Row.
Dwyer, F. R., Schurr, P. H., \& Oh, S. (1987). Developing buyer-seller relationships. Journal of Marketing, 51, 11-27.

Edvardsson, B., Tronvoll, B., \& Gruber, T. (2011). Expanding understanding of service exchange and value co-creation: a social construction approach. Journal of the Academy of Marketing Science, $39,327-339$

Eisenhardt, K. M., Kahwajy, J. L., \& Bourgeois, L. J., III. (1997). Conflict and strategic choice: How top management teams disagree. California Management Review, 39, 42-62.

Emerson, R. M. (1981). Social exchange theory. In M. Rosenberg \& R. Turner (Eds.), Social psychology: Sociological perspectives (pp. 30 65). New York: Basic Books.

Ferrell, O. C., \& Ferrell, L. (2008). A macromarketing ethics framework: stakeholder orientation and distributive justice. Journal of Macromarketing, 28, 24-32.

Fisk, G. (1967). Marketing systems: An introductory analysis. New York: Harper and Row.

Fournier, S., \& Lee, L. (2009). Getting brand communities right. Harvard Business Review, 87, 105-111.

Freeman, R. E. (1984). Strategic management: A stakeholder approach. Boston: Pitman.

Freeman, R. E. (1999). Divergent stakeholder theory. Academy of Management Review, 24, 233-236.

Frow, P., \& Payne, A. (2011). A stakeholder perspective of the value proposition concept. European Journal of Marketing, 45, 223-240.

Garriga, E. (2009). Cooperation in stakeholder networks: firms' 'tertius iungens' role. Journal of Business Ethics, 90, 623-637.

Gebhardt, G. F., Carpenter, G. S., \& Sherry, J. F., Jr. (2006). Creating a market orientation: a longitudinal, multifirm, grounded analysis of cultural transformation. Journal of Marketing, 70, 37-55.

Gilbert, N. G. (2008). Agent-based models. Thousand Oaks: Sage.

Granovetter, M. (1985). Economic action and social structure: the problem of embeddedness. American Journal of Sociology, 91, 481-510.

Greenpeace (2013). Greenpeace takes on Europe's biggest carmaker... and wins! http://www.greenpeace.org/international/en/news/Blogs/ makingwaves/greenpeace-takes-on-vw/blog/44214/

Grönroos, C. (1990). Service management and marketing: Managing the moments of truth in service competition. New York: Lexington Books.

Gummesson, E. (2008). Extending the service-dominant logic: From customer centricity to balanced centricity. Journal of the Academy of Marketing Science, 36, 15-17.

Gundlach, G. T., \& Wilkie, W. L. (2009). The American marketing association's new definition of marketing: perspective and commentary on the 2007 revision. Journal of Public Policy \& Marketing, 28, 259-264.

Harrison, J. S., \& Freeman, R. E. (2004). Is organizational democracy worth the effort? Academy of Management Executive, 18, 49-53.

Haytko, D. L. (2004). Firm-to-firm and interpersonal relationships: perspectives from advertising agency account managers. Journal of the Academy of Marketing Science, 32, 312-328.

Hill, C. W. L., \& Jones, T. M. (1992). Stakeholder-agency theory. Journal of Management Studies, 29, 131-154.

Hill, R. P., \& Martin, K. D. (2014). Broadening the paradigm of marketing as exchange: a public policy and marketing perspective. Journal of Public Policy \& Marketing, 33, 17-33.

Homburg, C., Stierl, M., \& Bornemann, T. (2013). Corporate social responsibility in business-to-business markets: how organizational customers account for supplier corporate social responsibility engagement. Journal of Marketing, 77, 54-72.

Hult, G. T. M. (2011). Market-focused sustainability: market orientation plus! Journal of the Academy of Marketing Science, 39, 1-6.

Hult, G. T. M., Mena, J. A., Ferrell, O. C., \& Ferrell, L. (2011). Stakeholder marketing: a definition and conceptual framework. AMS Review, 1, 44-65. 
Huy, Q. N. (1999). Emotional capability, emotional intelligence, and radical change. Academy of Management Review, 24, 325-345.

Iacobbuci, D. (1996). Networks in marketing. Thousand Oaks: Sage.

Ingenbleek, P. T. M., \& Immink, V. M. (2010). Managing conflicting stakeholder interests: an exploratory case analysis of the formulation of corporate social responsibility standards in the Netherlands. Journal of Public Policy \& Marketing, 29, 52-65.

Jolibert, A., Mühlbacher, H., Flores, L., \& Dubois, P.-L. (2012). Marketing management; A value-creation process. Houndsmill: Palgrave Macmillan.

Jones, T. M. (1995). Instrumental stakeholder theory: a synthesis of ethics and economics. Academy of Management Review, 20, 404- 437.

Jones, J. M., \& Ritz, C. J. (1991). Incorporating distribution into new product diffusion models. International Journal of Research in Marketing, 8, 91-112.

Jones, T. M., \& Wicks, A. C. (1999). Convergent stakeholder theory. Academy of Management Review, 24, 206-221.

Jurgens, M., Berthon, P., Papania, L., \& Shabbir, H. A. (2010). Stakeholder theory and practice in Europe and North America: the key to success lies in a marketing approach. Industrial Marketing Management, 39, 769-775.

Koll, O., Woodside, A. G., \& Mühlbacher, H. (2005). Balanced versus focused responsiveness to core constituencies and organizational effectiveness. European Journal of Marketing, 39, 1166-1183.

Kotler, P. (1972). A generic concept of marketing. Journal of Marketing, $36,46-54$.

Laszlo, C., Sherman, D., Whalen, J., \& Ellison, J. (2005). Expanding the value horizon: how stakeholder value contributes to competitive advantage. Journal of Corporate Citizenship, 20, 65-76.

Layton, R. A. (2007). Marketing systems: a core macromarketing concept. Journal of Macromarketing, 27, 227-242.

Lehmann, D. R. (2005). Journal evaluation and the development of marketing. Journal of Public Policy \& Marketing, 24, 137-142.

Leonard-Barton, D. (1995). Wellsprings of knowledge: Building and sustaining the sources of innovation. Boston: Harvard Business School Press.

Levitt, T. (1960). Marketing myopia. Harvard Business Review, 38, 4556.

Lewin, J. E., Strutton, D., \& Paswan, A. K. (2011). Conflicting stakeholder interests and natural gas: a macromarketing perspective. Journal of Macromarketing, 31, 340-358.

Lewis, M. W. (2000). Exploring paradox: toward a more comprehensive guide. Academy of Management Review, 25, 760-776.

Luo, X., \& Bhattacharya, C. B. (2009). The debate over doing good: corporate social performance, strategic marketing levers, and firmidiosyncratic risk. Journal of Marketing, 73, 198-213.

Lusch, R. F., \& Webster, F. E. (2011). A stakeholder-unifying, cocreation philosophy for marketing. Journal of Macromarketing, 31, 129134.

MacInnis, D. J. (2011). A framework for conceptual contributions in marketing. Journal of Marketing, 75, 136-154.

Maignan, I., \& Ferrell, O. C. (2004). Corporate social responsibility and marketing: an integrative framework. Journal of the Academy of Marketing Science, 32, 3-19.

Mele, C., Pels, J., \& Storbacka, K. (2015). A holistic market conceptualization. Journal of the Academy of Marketing Science, 43, 100-115.

Merchant, N. (2013). When TED lost control of its crowd. Harvard Business Review, 91, 78-83.

Miles, R. E., Snow, C. C., Meyer, A. D., \& Coleman, H. J. (1978). Organizational strategy, structure, and process. Academy of Management Review, 3, 546-562.

Mitchell, R. K., Agle, B. R., \& Wood, D. J. (1997). Toward a theory of stakeholder identification and salience: defining the principle of who and what really counts. Academy of Management Review, 22, 853888 .
Morgan, R. M., \& Hunt, S. D. (1994). The commitment-trust theory of relationship marketing. Journal of Marketing, 58, 20-38.

Murray, K. B., \& Montanari, J. B. (1986). Strategic management of the socially responsible firm: integrating management and marketing theory. Academy of Management Review, 11, 815-827.

Neville, B., \& Menguc, B. (2006). Stakeholder multiplicity: toward an understanding of the interactions between stakeholders. Journal of Business Ethics, 66, 377-391.

Norman, P. M., Palich, L. E., Parrack Livingstone, L., \& Carini, G. R. (2004). The role of paradoxical logic in innovation: the case of intel. Journal of High Technology Management Research, 15, 51-71.

Oliver, C. (1991). Strategic responses to institutional processes. Academy of Management Review, 16, 145-179.

Palmatier, R. W., Dant, R. R., Grewal, D., \& Evans, K. R. (2006). Factors influencing the effectiveness of relationship marketing: a meta-analysis. Journal of Marketing, 70, 136-153.

Parmar, B. L., Freeman, R. E., Harrison, J. S., Wicks, A. C., Purnell, L., \& de Colle, S. (2010). Stakeholder theory: the state of the art. Academy of Management Annals, 4, 403-445.

Payne, A., \& Frow, P. (2005). A strategic framework for customer relationship management. Journal of Marketing, 69, 167-176.

Poole, M. S., \& van de Ven, A. H. (1989). Using paradox to build management and organization theories. Academy of Management Review, 14, 562-578.

Prahalad, C. K. (2004). The cocreation of value. Journal of Marketing, $68,23$.

Preston, L. E., \& Donaldson, T. (1999). Stakeholder management and organizational wealth. Academy of Management Review, 24, 619620.

Reinartz, W., Krafft, M., \& Hoyer, W. D. (2004). The customer relationship management process: its measurement and impact on performance. Journal of Marketing Research, 41, 293-305.

Ritter, T., \& Gemünden, H. G. (2003). Network competence: its impact on innovation success and its antecedents. Journal of Business Research, 56, 745-755.

Rowley, T. J. (1997). Moving beyond dyadic ties: a network theory of stakeholder influences. Academy of Management Review, 22, 887910.

Senge, P. M. (1990). The fifth discipline: The art and practice of the learning organization. New York: Doubleday/Currency.

Shah, D., Rust, R. T., Parasuraman, A., Staelin, R., \& Day, G. S. (2006). The path to customer centricity. Journal of Service Research, 9, 113-124

Sheth, J. N., Sethia, N. K., \& Srinivas, S. (2011). Mindful consumption: a customer-centric approach to sustainability. Journal of the Academy of Marketing Science, 39, 21-39.

Shipilov, A. V., \& Li, S. X. (2012). The missing link: the effect of customers on the formation of relationships among producers in the multiplex triads. Organization Science, 23, 472-491.

Siguaw, J. A., Simpson, P. M., \& Baker, T. L. (1998). Effects of supplier market orientation on distributor market orientation and the channel relationship: the distributor perspective. Journal of Marketing, 62, 99-111.

Sisodia, R. S., Wolfe, D. B., \& Sheth, J. N. (2007). Firms of endearment; how world-class companies profit from passion and purpose. Upper Sadle River: Wharton School Publishing.

Smith, W. K., \& Lewis, M. W. (2011). Toward a theory of paradox: a dynamic equilibrium model of organizing. Academy of Management Review, 36, 381-403.

Smith, N. C., Drumwright, M. E., \& Gentile, M. C. (2010). The new marketing myopia. Journal of Public Policy \& Marketing, 29, 4-11.

Styhre, A. (2002). Thinking with AND: management concepts and multiplicities. Organization, 9, 459-475. 
Surroca, J., Tribó, J. A., \& Waddock, S. (2010). Corporate responsibility and financial performance: the role of intangible resources. Strategic Management Journal, 31, 463-490.

Tampio, N. (2010). Multiplicity. In M. Bevir (Ed.), Encyclopedia of political theory (Vol. 2, pp. 911-912). Thousand Oaks: Sage.

Tax, S. S., McCutcheon, D., \& Wilkinson, I. F. (2013). The Service Delivery Network (SDN): a customer-centric perspective of the customer journey. Journal of Service Research, 16, 454-470.

Van Bruggen, G. H., Antia, K. D., Jap, S. D., Reinartz, W. J., \& Pallas, F. (2010). Managing marketing channel multiplicity. Journal of Service Research, 13, 331-340.

Vargo, S. L. (2011). Market systems, stakeholders and value propositions; toward a service-dominant logic-based theory of the market. European Journal of Marketing, 45, 217-222.

Vargo, S. L., \& Lusch, R. F. (2004). Evolving to a new dominant logic for marketing. Journal of Marketing, 68, 1-17.

Vargo, S. L., \& Lusch, R. F. (2008). Service-dominant logic: continuing the evolution. Journal of the Academy of Marketing Science, 36, 1-10.

Vargo, S. L., \& Lusch, R. F. (2011). It's all B2B... and beyond: toward a systems perspective of the market. Industrial Marketing Management, 40, 181-187.
Verhoef, P. C., \& Leeflang, P. S. H. (2009). Understanding the marketing department's influence within the firm. Journal of Marketing, 73, 14-37.

Vince, R., \& Broussine, M. (1996). Paradox, defense and attachment: accessing and working with emotions and relations underlying organizational change. Organization Studies, 17, 1-21.

Wasserman, S., \& Faust, K. (1994). Social network analysis: Methodology and applications. NY: Cambridge University Press.

Wathne, K. H., \& Heide, J. B. (2004). Relationship governance in a supply chain network. Journal of Marketing, 68, 73-89.

Webster, F. E., Jr., \& Lusch, R. F. (2013). Elevating marketing: marketing is dead! long live marketing! Journal of the Academy of Marketing Science, 41, 389-399.

Webster, F. E., Jr., Malter, A. J., \& Ganesan, S. (2005). The decline and dispersion of marketing competence. Sloan Management Review, $46,35-43$.

Westenholz, A. (1993). Paradoxical thinking and change in the frames of reference. Organization Studies, 14, 37-58.

Wood, D. J., \& Jones, R. E. (1995). Stakeholder mismatching: a theoretical problem in empirical research on corporate social performance. The International Journal of Organizational Analysis, 3, 229-267. 